\title{
Experimental Study to Improves Covid-19 Health Protocol Compliance with High Threat and High Efficacy Poster
}

\section{Studi Eksperimen Meningkatkan Kepatuhan Protokol Kesehatan Covid-19 Dengan Poster Ancaman Tinggi dan Efikasi Tinggi}

\author{
Eric Fernardo ${ }^{1}$ \\ ${ }^{1}$ Pasca-Sarjana Departemen Komunikasi FISIP Universitas Indonesia, Jl. Salemba Raya No. 4, \\ Kenari, Senen, Jakarta Pusat 10430* \\ Email:eric.fernardo01@ui.ac.id
}

Masuk tanggal : 06-04-2021, revisi tanggal : 07-06-2021, diterima untuk diterbitkan tanggal : 15-07-2021

\begin{abstract}
This study examines the health campaign of Covid-19 using the extended parallel process model (EPPM) theory. The objective and gap that was successfully filled by this research are to examine the effect of the poster with high threat and high efficacy to obedience to implement Covid-19 health protocol in Indonesia context. In contrast, obedience is divided into aspects of attitude and second aspects of behaviour according to Blass's concept of obedience. This study uses a quantitative approach with an experimental method by grouping respondents into two groups. The first is the treatment group that received a poster. The second is a control group that did not receive any posters. The total number of respondents of this research was 95 , representing proportionally by categories of sex and categories of age. This research has met the scientific principles required. This study found that poster with high threat and high efficacy has a significant effect of improving the attitude aspects of obedience to implement Covid-19 health protocol because when respondents saw a poster with high threat and high efficacy, respondents felt that the threat posed by covid-19 was so high that could turn into death, another reason is a poster with high threat, and high efficacy evokes the memory of respondents to remember their relatives, close person or family who have been confirmed positive with Covid-19 virus. This study also found that poster with high threat and high efficacy does not affect behavioural aspects. This means that posters with high threat and high efficacy proved to make changes with the attitude aspects to improve people obedience to implement Covid19 health protocol but, it has not been proven to change the behavioural aspects.
\end{abstract}

Keywords: Covid-19, extended parallel process model, health campaign, obedience

\begin{abstract}
Abstrak
Riset ini meneliti kampanye kesehatan Covid-19 menggunakan pisau analisa teori extended parallel process model (EPPM). Tujuan dan celah yang berhasil diisi dari penelitian ini dibandingkan penelitian terdahulu adalah menguji pengaruh pemberian poster ancaman tinggi dan efikasi tinggi terhadap kepatuhan protokol kesehatan Covid-19 dalam konteks Indonesia, adapun kepatuhan dibagi ke dalam dua aspek yakni aspek sikap dan aspek perilaku sesuai konsep kepatuhan Blass. Penelitian ini menggunakan pendekatan kuantitatif yakni metode eksperimen dengan membagi responden ke dalam dua kelompok yang pertama adalah kelompok perlakuan/treatment yang mendapat poster dan kedua adalah kelompok kontrol yang tidak mendapat poster, jumlah responden sebanyak 95 yang
\end{abstract}


mewakili masing-masing kategori jenis kelamin dan kategori usia secara proporsional. Riset ini telah dilaksanakan mengacu pada kaidah-kaidah ilmiah. Hasil penelitian menemukan bahwa pemberian poster ancaman tinggi dan efikasi tinggi berpengaruh signifikan meningkatkan aspek sikap kepatuhan protokol kesehatan Covid-19 karena saat melihat poster ancaman tinggi dan efikasi tinggi responden merasa ancaman yang ditimbulkan oleh Covid-19 amat besar hingga dapat menimbulkan kematian, alasan lain yakni poster ancaman tinggi dan efikasi tinggi membangkitkan memori responden yang teringat orang dekat, kerabat maupun keluarga yang pernah terkonfirmasi positif virus Covid-19. Penelitian ini juga menemukan bahwa poster ancaman tinggi dan efikasi tinggi tidak berpengaruh terhadap aspek perilaku. Artinya pemberian poster ancaman tinggi dan efikasi tinggi terbukti mengubah aspek sikap untuk lebih mematuhi protokol kesehatan Covid-19 tetapi, tidak terbukti mengubah aspek perilaku.

Kata Kunci: Covid-19, extended parallel process model, kampanye kesehatan, kepatuhan

\section{Introduction}

In December 2019, a new virus emerged, SARS-CoV-2, better known as Covid-19 (Corona Virus Disease 2019), first discovered in the city of Wuhan, Hubei Province, the People's Republic of China, which has now spread to various parts of the world (Hui et al., 2020). It was recorded that until the end of 2020, there were 83 million people in the world who were confirmed positive for the Covid-19 virus (worldometers, 2020). In its development in Indonesia, this virus the end of 2020, has resulted in 743 thousand people being confirmed positive for the Covid19 virus (Satgas Covid-19, 2020). In the world itself, according to the world health agency or better known as the World Health Organization (WHO), the Covid-19 virus has been designated a pandemic (Ghebreyesus, 2020).

In the context of Indonesia, the government of the Republic of Indonesia has established a Task Force for the Acceleration of Handling Covid-19 through Presidential Decree No. 7 of 2020 in March 2020 (Keputusan Presiden 7, 2020) and a month later, precisely in April, the government officially declared Covid-19 a disaster. Non-natural national through Presidential Decree 12/2020 (Keputusan Presiden 12, 2020). In its development, the Task Force team transformed into the Committee for Handling Corona Virus Disease 2019 (Covid-19) and National Economic Recovery, which is familiarly abbreviated as KPC-PEN, which was formed based on Presidential Regulation Number 82 of 2020 (Peraturan Presiden $82,2020)$.

The Covid-19 virus is very fast in transmission because it can be transmitted through human interaction in the form of droplets that usually appear when humans talk, sneeze, cough, or touch various surfaces, including touching someone (Rothan \& Byrareddy, 2020). The transmission of the Covid-19 virus is quite tricky to avoid because this virus can also be transmitted to people who have not or do not have symptoms of illness. In Indonesia itself, the government has taken various policies to reduce the rate of transmission of the Covid-19 virus. For example, in February 2020, there had been Forbidding and restricting flights from or to the People's Republic of China (PRC) and other countries. The government has also issued various guidelines for Covid-19, including health protocols, border control 
Eric Fernardo:

Experimental Study Improves Covid-19 Health Protocol Compliance With High Threat and High Efficacy poster

Studi Eksperimen Meningkatkan Kepatuhan Protokol Kesehatan Covid-19 Dengan Poster Ancaman Tinggi dan Efikasi Tinggi

protocols, communication protocols, and educational institution area protocols. As well as protocols for public areas and transportation (Kementerian Kesehatan, 2020).

The Indonesian government has also made various other efforts to anticipate the spread of the Covid-19 virus, for example, the implementation of Large-Scale Social Restrictions (PSBB) to prevent the emergence of crowds that can become clusters of distance where this PSBB can be enforced by the Provincial Government and Regency/City Governments after receiving approval of the Minister of Health as outlined in the Decree of the Minister of Health (Peraturan Menteri Kesehatan 9, 2020). Efforts that are also encouraged by the government are a series of health campaigns to the community so that each individual can take various preventive measures, including wearing masks, washing hands, and maintaining distance (KPC-PEN, 2020).

The widespread of the Covid-19 virus, which has been designated as a pandemic by WHO, has made researchers interested in studying the extended parallel process model (EPPM) theory developed by Kim Witte. The EPPM theory is often used to examine the effects of communication campaigns in the health sector. On the behaviour or attitudes of the people who receive the campaign. Several studies examine various health campaigns using the EPPM theory, for example, research conducted by Shirahmadi et al. in 2020 which in its findings found that the higher the level of threat and the higher the level of efficacy will further encourage the desire of health workers in the dental health sector to comply with the behaviour. Live clean and take various preventive measures to prevent themselves from contracting the Covid-19 virus. This is also driven by the understanding of health workers on the potential for the spread of the Covid-19 virus (Shirahmadi et al., 2020).

In addition to Shirahmadi, other research that discusses Covid-19 and health campaigns can also be found in a study conducted by Lee and You in 2020 in South Korea, which in its findings explains that when people psychologically feel themselves potentially or vulnerable to being exposed to the Covid-19 virus then will encourage the behaviour to take various measures to prevent the spread of the Covid-19 virus such as maintaining distance, using masks and avoiding crowds, meaning that individual psychological responses will have a direct impact on behaviour to comply with health protocols (Lee \& You, 2020).

Subsequent research conducted by Jahangiry et al. in 2020 in Iran found that in the context of the application of the EPPM theory in the Covid-19 pandemic, it found that more than half or the majority of respondents would carry out hazard control compared to those who controlled fear, meaning that in the Covid-19 pandemic the majority of the people in Iran will implement clean and healthy living behaviour because the Covid-19 virus is considered accurate and can be transmitted to anyone (Jahangiry et al., 2020).

In addition, there is also research in 2020 conducted by Jingwen yang et al. doing testing experiments related to the influence of reps provision of health campaign where there are two groups, namely the first group was only given a onetime health campaign, while the second group was given twice a health campaign or in other words to get the repetition, in the hypothesis Jingwen yang et al. 
considered that the more often people get repetition health campaign will increase the awareness to comply with the protocol health or behave clean (Yang et al., 2020).

Depart from several previous research that became the benchmark of this research, when at earlier research, Shirahmadi respondents are health workers (Shirahmadi et al., 2020) or Jahangiry who do not grant poster (Jahangiry et al., 2020), while Lee and You explain that the behaviour of healthy life will be done if people feel can be affected by the Covid-19 (Lee \& You, 2020), and Jingwen Who along with his team who did the study of the influence of the frequency of the provision of health campaigns against the awareness to comply with the protocols of health (Yang et al., 2020). In the phenomenon of the pandemic Covid-19 that occurred this, researchers use a knife analysis of the theory of the extended parallel process model (EPPM) will be assessed in the context of Indonesia to determine the effect of posters a high threat and high efficacy compliance to the protocol of health Covid-19.

In health communication, one theory is the extended parallel process model (EPPM) developed by Kim Witte. This theory examines how people manage fear, which appears when the given threat message is from a different (Littlejohn et al., 2017). One of the key aspects in observing the behaviour of health is a sense of fear, even the fear is often used as the main motivator, and fear often want to appear in the messages of health communication to encourage healthy behaviours in the community or vice versa can encourage people to behave in unhealthy (Littlejohn et al., 2017). An example of study EPPM is a campaign that voiced the public not to drive after drunk because such behaviour can make the culprit was arrested by the police or injury others, the conditions are arrested the police or injury to others is certainly due to a dreaded lot of people so when given the book so should make the individual is no longer driving in a state of drunkenness. However, in general, there are still many people that keep driving in a state of drunkenness, that campaign who voiced the public not to drive is not always able to persuade people to change their behaviour; the theory of EPPM seeks to explain how the onset of fear can result in healthy behaviour in the society because of exposure to campaign information health (Littlejohn et al., 2017).

The approach of fear (fear appeal) can be defined according to its content or based on the audience's reaction. According to its content approach, fear contains loads of content scary with explicit language, the language that is personal or horrible images (Witte, 1992). While referring to the audience's reaction, the approach to fear is judged based on the experience of the physiological or psychological audience. The response of the audience is usually evaluated by checking the manipulation in which the approach of the fear that the high increase of reaction of fear that is high compared to the approach of the fear that low (Witte, 1992). The approach of fear is a book designed to encourage a change in behaviour of a person to protect themselves from emerging threats. There are two components in the message the approach of the fear component that shows how significant a threat could potentially arise as a result of doing something, and the second component is the recommended actions to prevent this (O'keefe, 2016) 
Eric Fernardo:

Experimental Study Improves Covid-19 Health Protocol Compliance With High Threat and High Efficacy poster

Studi Eksperimen Meningkatkan Kepatuhan Protokol Kesehatan Covid-19 Dengan Poster Ancaman Tinggi dan Efikasi Tinggi

Two key factors that each has a relationship to explain how someone responds to the message with the approach of the fear, the first of which is a threat received, where the degree of threat in the form of high or low will affect the vulnerability of the person against danger, the threat is divided into two elements, namely the level of severity against the threat in the form of how likely a result may arise from the behaviour that is done, and the level of susceptibility to threats in the form of how likely a result will occur from a behaviour that is performed (Littlejohn et.al., 2017). A key factor the second is the efficacy perceived, i.e., the ability of a person to perform various actions to the recommendations given to avoid the threat that may arise. There are two elements of the efficacy perceived, i.e., response efficacy in the form of how it may prevent an action can prevent the person from the consequences that arise, for example by avoiding drinking how might be spared from traffic accidents; the second element, namely the efficacy of the self in the form of ability to perform the actions recommended to avoid the threat (Littlejohn et.al., 2017).

Theory EPPM provides a framework to examine the relationship between threat, fear, and the effects of persuasion. EPPM concentrated on the factors that affect the protective action by identifying the perceived threat and efficacy perceived as the direct influence of defensive measures that depart from the assumption that the perceived threat is influenced from the high-low threat in the message while the effectiveness perceived influenced of response efficacy (O'keefe, 2016). Furthermore, the EPPM identifies two parallel processes different from the approach of fear, the first person will control the hazards that may arise or the second person will manage the fear in her, the difference is dependent on the combination between the perceived threat and efficacy perceived each individual (O'keefe, 2016).

The theory that was initiated by Kim Witte offers three reactions that will emerge from the individual messages health communication, among others, the first, the individual may choose not to respond at all an example is someone who listens to health campaigns don't drive in a state of intoxication will be ignored health campaign that if he was not a drinker-liquor; the second reaction is the control of fear which is a response that involves the control of fear in him against a threat that may arise, the answer is usually appear when a person does not have the ability to control what might happen to himself, therefore, then what to do is control the fear in her to ignore the message of the campaign health, the difference in the reaction of the second and the first (no response at all) are in the second reaction, this person does not make recommendations of action due to dampen the anxiety that was in him; the reaction of the third is the control of hazards is the act of a person do when feeling himself able to control what may happen to her and manifested in the form of performing a series of actions to prevent the dangers which may arise for example looking for more detailed information, talk with your family or officer of health, or perform actions of a concrete recommended (Littlejohn et.al., 2017).

The basic assumptions of the EPPM are when a person receives communication messages with high threat and high efficacy. The action that arises is the control process of the danger in which a person understands the dangers that 
can arise due to doing things and put himself to comply with the recommendations of the action provided to prevent such hazards. In contrast, when the message communication is a low threat and efficacy is low. Action arising out is the process of control the fear, in which someone will drown out the fears that arise in him and do not make recommendations of action on offer (O'keefe, 2016).

In 1999, Thomas Blass developed the concept of compliance of the paradigm Milgram. The study results from the extrapolation of the study-the study of compliance have grown to thirty-five years earlier. The study of compliance is one of the studies discussed much in the social sciences. Interesting findings in the research extrapolation Blass is compliance is a behaviour that is receiving the messages given by the authorities and experts, both related to the expectations and the reality of compliance showed no distance too far that when the researchers predict that a person will obey then the results of the experiment will also thus, the third almost in most studies found no difference in compliance between the gender male or female that gender does not affect the compliance, fourth there is no change in the level of compliance drastically in the development of the era that time of the experiments given did not significantly change the behaviour of the compliance person (Blass, 1999).

In its development, the behaviour of this compliance can be divided into two aspects, namely aspects of attitude and behavioural aspects. The aspect of attitude is closely related to the dimension of trust (belief) and receive (accept), while aspects of the conduct are related to the dimensions of the perform (act) itself (Hartono, 2006). Dimensions of trust, namely, a person will behave obediently if trust there is one important goal of establishing regulations/guidelines/protocols given (Andriyuni, 2018). As an example related to the dimensions of trust, this is in the context of the relationship between the students with a Kiai, a student believes that comply with the directives of the Kiai will give blessing while if it does not comply with the direction of Kiai will result in knowledge that is obtained is not beneficial so that it encourages the attitude of students to meet the dimensions of trust and comply with Kiai (Hartono, 2006).

The receive (accept) dimensions are closely related to the acceptance of a person against a series of rules/guidelines/protocols given (Andriyuni, 2018). The form of this acceptance can be in the form of the absence of debate or a sense of doubt over the rules/guidelines/protocols that exist, is in again this acceptance can be shaped not have the courage to question the rules/guidelines/protocols, there is no rejection of the rules/guidelines/protocols are given, to accept wholeheartedly the rules/guidelines/protocols that are and are not contradict it (Hartono, 2006) however, the dimensions of the receiving is still covered in the aspect of attitude, that needs to be studied more in its impact on behaviour.

Dimensions perform (act) is consciously making various rules/guidelines/protocols that exist as an actual embodiment of the attitude of trust and accept the rules/guidelines/protocols that have been given (Andriyuni, 2018). Conduct in the context of the act of doing the behaviour in accordance with what are the rules/guidelines/protocols that have been established. In this experiment, the dimensions of the do are divided in the form of performing actions according to the rules/guidelines/protocols that exist (Amal \& Rusmawati, 2019), no violation of 
Eric Fernardo:

Experimental Study Improves Covid-19 Health Protocol Compliance With High Threat and High Efficacy poster

Studi Eksperimen Meningkatkan Kepatuhan Protokol Kesehatan Covid-19 Dengan Poster Ancaman Tinggi dan Efikasi Tinggi

rules/guidelines/protocols that exist and promulgate rules/guidelines/protocols that exist.

Academically, the goals of this research will fill the void that has not been presented by previous research through the experimental method of study that will test the effect of the poster compliance to the protocol of health Covid-19 in the general public. While from the practical side, the results of this research can be a reference for stakeholders or policymakers to create strategies for health communication effective in improving the attitudes and behaviour of the community in complying with the protocol of health Covid-19.

Researchers distinguish the dimensions of the attitude from the dimensions of behaviour in addition because in the concept of the dimensions of the attitude and the behavioural dimension is two different things (Hartono, 2006), researchers also want to understand in more detail the extent to which the provision of the poster influence on aspects of the attitude of the respondents to comply with the protocols of health Covid-19 as well as aspects of the behaviour of the respondents to comply with the protocols of health Covid-19. Departing from the idea of the theory of the extended parallel process model (EPPM) and the concept of compliance, this study will assess the effect of the campaign approach fear in the form of high threat and high efficacy against the attitude and behaviour of the community to adhere to the protocols of health Covid-19. The hypothesis that the campaign is a high threat and high efficacy significantly influence aspects of the attitude of society to comply with the protocols of health Covid-19, while the hypothesis that both the campaigns are a high threat and high efficacy significantly influence aspects of people's behaviour to comply with the protocols of health Covid-19.

\section{Research Method}

In the process of collecting data, the research paradigm used in this study is a post-positivistic, basically post-positivistic depart from the basic assumptions of positivism, which considered that social reality is something that is real and can be studied and examined using a set of methods that apply universally or in other words the research must be in replication by other researchers. Therefore, researchers should keep a distance from the object to be studied and take a free position value in assessing the social reality; this paradigm encourages researchers to behave objectively and exclude the values, ethics, impartiality, and moral choices that exist in the researcher during the research process, this research is deductive because the researchers started the study of the theory and the hypotheses that have been there for later tested in this study (Neuman, 2014). The reason the researchers using the paradigm of a post-positivistic is to fill in gaps if using the paradigm of positivistic, that gap is because the object being studied is the man who can create, manage, share, interpret the meaning then it is difficult to find a social reality based only on data and statistics. Therefore the results of data processing and statistics will be explored in more depth by researchers to answer the reason behind proven or not proven a theory and a tested hypothesis (Bisel \& Adame, 2017). 
The approach used in this research is a quantitative approach to find the social reality. This approach will perform a series of measurements objectively through the processing of numbers and data in statistics. Quantitative research departs from the common things to specific things or, in other words, the study based on a theoretical explanation to explain the hypothesis of the phenomenon to be studied and test the hypothesis (Babbie, 2008). As for the steps in the quantitative approach, among others, first, decide on a research topic; second, determining the focus of the above matters to be examined; third, designing research with grounded than used for previous studies to answer the question that was about to be tested; the fourth, perform data collection in the form of numbers that will be processed statistically; the fifth, the analysis of the data; the sixth, the interpretation of the data; the seventh, do a conclusion (Neuman, 2014).

The research method in this research is an experiment because, as the purpose of this research is to test the influence of independent variables on the dependent variable, the researcher will provide treatment/treatment to the respondent and control to minimize the impact of factors outside the independent variables studied (Wimmer \& Dominick, 2003). Research methods experiments were used to perform testing and provide an explanation for the influence between the variables studied, the excellence of the research experiment is considered to be able to control the bias that may arise in the research because the main characteristic of the method of an investigation is the group that gets the treatment/treatment and control groups to ensure that the influence of treatment/treatment is done real (Neuman, 2014).

The population in this research are Indonesian citizens aged over the age of eighteen (18) years of age. Researchers divided respondents into two categories: the first category by gender, i.e., male and female, as well as the second category based on the age groups, i.e., age 18-41 years old and the age of 41 above of the reason for the decision of the respondents to include people from various age groups are divided in young adults (18-41 years) and adults (41 years and above), as well as the gender, divide proportionally so that could represent the population of Indonesia, which has the population balanced between men and women. The technique of sampling is done in quota sampling, which will form groups of respondents proportionately to obtain a representation of each category (Neuman, 2014).

Furthermore, in data collection, the control group is not given treatment/treatment and then immediately fills out the online questionnaire ratings. At the same time, the treatment group/treatment will be presented with a poster of high threat and high efficacy before filling out the questionnaire assessment online. The involvement of the respondents is voluntary but mandatory to follow the study until the end. Respondents in the study were 95, which is divided proportionally based on gender and age group. Furthermore, the data analysis technique in this research is to test the analysis of variance (ANOVA) one way to determine whether or not the influence of independent variables on the dependent variable as well as the difference in treatment/treatment between two or more groups (Nuryadi et al., 2017) the next data will be processed using the application of Statistical Product and Service Solutions (SPSS). 
Eric Fernardo:

Experimental Study Improves Covid-19 Health Protocol Compliance With High Threat and High Efficacy poster

Studi Eksperimen Meningkatkan Kepatuhan Protokol Kesehatan Covid-19 Dengan Poster Ancaman Tinggi dan Efikasi Tinggi

The concept of measurement in this research is to test the effect of independent variables on the dependent variable. The independent variables studied were the treatment/treatment administration poster with high threat and high efficacy that suggests that the Covid-19 threat very seriously for the sufferer to cause death, as for the illustration used is a picture of the cemetery with the protocol Covid-19, as well as images of bodies of Covid-19 (Shirahmadi et al., 2020) that will be compared with, is not given poster at all; the dependent variable being tested is the obedience which is divided into the aspects of attitude in the form of the dimensions of trust (belief) and the dimensions of the receive (accept), as well as behavioural aspects such as the dimensions, do (action) according to the concept of compliance, which was initiated by Thomas Blass (Hartono, 2006).

\section{Result and Discussion}

Experimental research conducted by the researcher will examine the difference in influence between the groups of respondents who provided a poster with a high threat and high efficacy, as well as the control group, were not given a poster at all. As a note, the researchers found no significant differences between groups of respondents if divided into the category of age or gender. Before processing the data further, the researcher will first perform a validity test is a test to measure how valid a test performed in this experiment included a questionnaire used by the researcher will be tested for its validity, it is important to do because an experiment belongs to the questionnaire in it that is proven to be valid will produce data which amends the minimal given in the measurement in the social sciences are different with measurement in the natural sciences because in the social sciences involving human; valid in this case prove testing conducted by researchers can properly measure the test is done correctly (Ulum, 2016).

Table 1. Validity Test

\begin{tabular}{llll}
\hline No & Aspect & Dimension & Validity Test Result \\
1 & Attitude & Belief & 0,000 \\
2 & Accept & 0,000 \\
3 & Behaviour & Act & 0,000 \\
\hline \multicolumn{2}{r}{ Source: Primary Data Research }
\end{tabular}

In a test of validity, the researcher used to test validity - correlation test of Pearson Product Moment using an SPSS data processing, the results of which show that all measuring functions, including the questionnaire used by the researchers, is valid in testing because test results validity get significant results which are lower than 0.05 (Nuryadi et al., 2017).

Furthermore, the researchers will also conduct a reliability test that aims to determine reliable or consistent experiments conducted by researchers. No exception questionnaire was used in this study. The reliability test is essential in the social sciences because of the contrast with the natural sciences. In the social sciences, there are things outside of the object under study can affect the research so that researchers will have to prove first that the measurement used by researchers are reliable or reliable, by proving that the experiment including the questionnaire 
data showed that the measurement tool used by researchers to be reliable, used over and over (Ulum, 2016).

Table 2. Reliability Test

\begin{tabular}{llll}
\hline No & Aspect & Dimension & Reliability Test Result \\
1 & Attitude & Belief & Accept \\
2 & Behaviour & Act & 0,823 \\
3 & \multicolumn{2}{c}{ Source: Primary Data Research }
\end{tabular}

Using reliability testing with coefficient of Cronbanch's Alpha. The researchers get the reliability test results with numbers 0,823 . In testing Cronbanch's Alpha, an experiment including the questionnaire was said to be reliable if it shows results of greater than 0.60 (Nuryadi et al., 2017). Reliability test results obtained the researchers describe that the experiment measurement includes the questionnaire used in this research is reliable to perform the size. A measuring tool used by researchers can be relied upon to do the testing.

The researchers also conducted a test of homogeneity. A test is intended to test statistically and prove that the group of respondents who provided treatment/treatment and the control group derived from a population that the variance the same, homogeneity testing will prove whether the variance between the groups tested and the control group was the same or not, this means that researchers will first test the similarity of the characteristics of a group of respondents to research and prove that the respondents studied in this research come from a population the variance does not differ much in terms of diversity (Nuryadi et al., 2017).

This research test the homogeneity refers to the testing Levene using the software Statistical Product and Service Solutions (SPSS), based on the results of the test of homogeneity of the researchers get the data here:

Table 3. Homogeneity Test

\begin{tabular}{llll}
\hline No & Aspect & Dimension & Homogeneity Test Result \\
1 & Attitude & Belief & 0,761 \\
2 & Accept & 0,466 \\
3 & Behaviour & Act & 0,104 \\
\hline & & Source: Primary Data Research
\end{tabular}

Based on the reference of the table homogeneity test, it can be the result of that whole group of respondents who received treatment/treatment and the group of respondents of the control comes from a population that diversity is not much different or the same characteristics as the result of homogeneity test showed the data is more significant than 0.05 (Nuryadi et al., 2017).

After the data studied proved to be valid, reliable, and homogeneous, then the researcher will perform data processing for the statistical effect of the poster compliance to the protocol of health Covid-19, which is divided into two aspects, namely aspects of attitudes and factors of behaviour analysis using the $\mathrm{F}$ test is known by analysis of variance (ANOVA), the results of the test are as follows: 
Eric Fernardo:

Experimental Study Improves Covid-19 Health Protocol Compliance With High Threat and High Efficacy poster

Studi Eksperimen Meningkatkan Kepatuhan Protokol Kesehatan Covid-19 Dengan Poster Ancaman Tinggi dan Efikasi Tinggi

Table 4. The F test (ANOVA) poster Compliance

\begin{tabular}{|c|c|c|c|c|}
\hline No & Aspect & Dimension & F Result & Description \\
\hline 1 & & Belief & 0,036 & Significant \\
\hline 2 & Attitude & Accept & 0,018 & Significant \\
\hline 3 & Behaviour & Act & 0,106 & Not Significant \\
\hline
\end{tabular}

Based on the F test (ANOVA) results above, it was found that there is a significant influence between the independent variables against the dependent variable, meaning that the granting of posters considerable effect on compliance protocol health. However, compliance is the effect of this poster only significant effect on aspects of the attitude which the dimensions of trust (belief) and the dimensions of the acceptance (accept) and did not significantly influence the behavioural aspects with the dimensions do (act), these results can be drawn results of the F test value is below 0.05 only on the dimensions of trust and acceptance of the course.

Furthermore, this research aims to know the difference between treatment groups with the control group. The researchers will compare the differences between the groups given a poster a high threat and high efficacy with a group that is not given a poster when using Post-Hoc Tukey (Nuryadi et al., 2017). The result is the following:

Table 5. Post-Hoc Tukey Comparison of the Treatment Group and the Control

\begin{tabular}{lllll}
\hline No & Group & Aspect & Dimension & Description \\
1 & & Attitude & Belief & Accept \\
2 & Without posters & & Actignificant \\
3 & & Behaviour & Act & Not Significant \\
4 & posters with High & Attitude & Belief & Not Significant \\
5 & Threat and High & Accept & Significant Increase \\
6 & Efficacy & Behaviour & Act & Significant Increase \\
\hline
\end{tabular}

Source: Primary Data Research

From the test results of the Post Hoc-Tukey, the results of the study showed that when respondents were not given poster when it does not influence the aspects of attitude and behavioural aspects to adhere to the protocols of health Covid-19 because it is not statistically significant, while when respondents have given a poster a high threat and high efficacy influence the aspects of attitude to comply with the protocols of health Covid-19 for the found test result is statistically significant. This study found that the attitude of the respondents to comply with the protocols of health Covid-19 affected significantly by giving the poster a high threat and high efficacy or in other words, poster is a high threat and effectiveness can be used to improve compliance with the protocol of health Covid-19 in the aspect of attitude.

To answer the research hypothesis proposed by the researcher that the first hypothesis that the campaign is a high threat and high efficacy significantly influences aspects of society's attitude to adhere to the protocols of health, Covid19 is received. In contrast, the second hypothesis that the campaign is a high threat 
and high efficacy significantly influence aspects of people's behaviour to comply with the protocols of health Covid-19 was denied. The research findings are the provision of a poster with high threat and high efficacy can improve aspects of society's attitude to adhere to the protocols of health Covid-19. However, the poster is a high threat, and high effectiveness is not proven to improve people's behaviour to comply with the protocols of health Covid-19.

Refers to the analysis of a statistical test of the hypothesis of the study, this research found that the posters are a high threat and efficacy only increases the compliance of the protocol of health Covid-19 in the aspect of attitude, of course, not proven statistically increase the adherence of the community in the form of behaviour. As the theory of the extended parallel process model (EPPM), which explained that when given a health campaign in the form of threat and efficacy, can someone give three responses which did not provide any response, control fear by rejecting the recommendations given, perform hazard control by accepting the recommendations given, the assumption of the theory of EPPM, which is when a person feels threatened it will encourage the emergence of motivation in yourself to take action, the higher the threat received, the greater the motivation to act to prevent the adverse effects that may arise (Littlejohn et al., 2017).

Still, in the extended parallel process model (EPPM) theory, the high efficacy that a person receives will push to control the hazard as is the control of hazards is make recommendations of action which campaigned to prevent the self is exposed to danger. In contrast, the efficacy of the low will encourage the control of fear that rejects the recommendations of the action that campaigned and keep doing actions that may result in him exposed to danger, so to encourage someone to do need to be given health, the campaign is a high threat and high efficacy (Littlejohn et al., 2017).

Compliance protocol health Covid-19 in this study refers to the concept of compliance proposed by Blass, namely compliance is divided into two aspects, namely aspects of an attitude consists of the dimensions of trust (belief) and receive (accept) as well as aspects of behaviour with the dimensions do (act) (Hartono, 2006). The results of this study show that the basic assumptions of the theory of EPPM that when a person receives a health campaign in the form of posters, a high threat and high efficacy significantly increase the compliance of the protocol of health Covid-19 in the aspect of attitude, however, has no significant effect in the part of behaviour.

Compared with previous research, the findings of this study showed similar results with the research of a kind conducted by the Shirahmadi and his team in Iran that in the respondents that contain health workers, health campaigns Covid-19 with a high threat and high efficacy will encourage the desire of health workers to comply with the clean life behaviour (Shirahmadi et al., 2020) that in the context of Indonesia is known with the term protocol of health Covid-19. The findings of this research also provide top of the study from Jahangiry et al. in the year 2020 in Iran, which concluded that in the pandemic, Covid-19 respondents would be more compelled to behave in a clean and healthy life because they feel anyone can be infected with the virus Covid-19 (Jahangiry et al., 2020) that is somewhat different is the previous studies combines aspects of attitude and behavioural aspects in the 
Eric Fernardo:

Experimental Study Improves Covid-19 Health Protocol Compliance With High Threat and High Efficacy poster

Studi Eksperimen Meningkatkan Kepatuhan Protokol Kesehatan Covid-19 Dengan Poster Ancaman Tinggi dan Efikasi Tinggi

one form, namely compliance, while this study divides the compliance into the aspects of attitude and behavioural aspects.

The researchers then asked the respondents why, when given a poster, it is a high threat. High efficacy significantly improves the aspects of attitude, namely the dimensions of trust and acceptance of the respondent to comply with the protocols of health Covid-19, the reasons stated by the respondents, namely when viewing a poster a high threat and high efficacy of the threat posed by Covid-19 is very great because it can cause death, another reason which poster with high threat and high efficacy also evokes the memory of respondents who recalled the close person, the family, and relatives who once confirmed positive of the virus Covid19.

This study reveals that the poster with high threat and high efficacy turns out only significantly influence aspects of the attitude of the respondents, but dont have significant effect on the behavioral aspects of the respondents to comply with the protocols of health Covid-19, as this can happen because before the given poster with high threat and high efficacy of the respondents have complied with the protocol of health Covid-19, before being given a poster a high threat and high effectiveness of the respondents are already accustomed to applying the protocol of health Covid-19, in addition, the responde also have the principle is better to prevent than to contracting the virus Covid-19, the behavior adhere to the protocols of health also push the massive news that instruct comply with the protocol for the health and well according to the respondents to comply with the laws and regulations that apply so as to avoid a fine, the other thing that encourages respondents to comply with the protocols of health is required by the public place such as an office or a shopping center, there are those who have friends or relatives or personal experience exposed to Covid-19 so that the poster with high threat and high efficacy does not significantly influence aspects of behavior because respondents had to adhere to the protocols of health Covid-19 any poster that it receives.

Recommendations for further research can be enriched by examining the respondents who are segmented, for example, groups of people who should be looking for income with activities outside the home or examine the level of compliance of the dimensions of the attitude and behaviour of people from the group who been vaccinated, so that it can increasingly provide an overview of the influence of health campaigns such as posters against the dimensions of the attitude and the behavioural dimension of society.

\section{Conclusion}

This research wants to fill the gap that has not been done in previous research in health campaigns, particularly the phenomenon of the pandemic Covid19 based on the blade of the analysis theory of the extended parallel process model (EPPM). The gap filled by this study is to determine the effect of giving the poster a high threat and efficacy of the compliance to the protocol of health Covid-19 in the context of Indonesia. This study divides the compliance protocol health Covid19 into two aspects, namely aspects of attitude and behavioural aspects. 
The study found when respondents have given a poster, a high threat and high efficacy. Significantly improve aspects of the attitude of the compliance protocol health Covid-19 for the time to see poster with high threat and high efficacy of the respondents assess the threat arising from Covid-19 to very high even can cause death or evoke memories of the respondents on the relatives and family of contracting the virus Covid-19. Still, the poster with high threat and high efficacy does not significantly influence the behavioural aspects of compliance protocol health because before the given poster is a high threat and effectiveness of the respondents already used to comply with the protocol health regardless before given poster with high threat and high efficacy or not.

\section{Reference}

Amal, I., \& Rusmawati, D. (2019). Hubungan School Well-Being Dengan Kepatuhan Menaati Tata Tertib Pada Siswa Smp N 4 Petarukan. Empati, 8(1), 49-54.

Andriyuni, N.H. (2018). Hubungan antara dukungan sosial teman sebaya dengan kepatuhan santri pada peraturan di pondok pesantren al-madienah denanyar jombang. Skripsi Universitas Mercu Buana Yogyakarta.

Babbie, E. (2008). The basics of social research (Edisi 4). California, Amerika Serikat: Thomson Wadsworth

Bisel, R. S., \& Adame, E. A. (2017). Post-Positivist/Functionalist Approaches. The International Encyclopedia of Organizational Communication, 1-22. https://doi.org/10.1002/9781118955567.wbieoc168

Blass, T. (1999). The milgram paradigm after 35 years: Some things we now know about obedience to authority. Journal of Applied Social Psychology, 29(5), 955-978. https://doi.org/10.1111/j.1559-1816.1999.tb00134.x

Ghebreyesus, T. A. (2020). WHO Director General's Speeches, March, 4. https://www.who.int/director-general/speeches/detail/who-directorgeneral-s-opening-remarks-at-the-media-briefing-on-covid-19---11-march2020

Hartono. (2006). Kepatuhan dan Kemandirian Santri (Sebuah Analisis Psikologis). Jurnal Studi Islam Dan Budaya, 4(1), 1-12.

Hui, D. S., I Azhar, E., Madani, T. A., Ntoumi, F., Kock, R., Dar, O., Ippolito, G., Mchugh, T. D., Memish, Z. A., Drosten, C., Zumla, A., \& Petersen, E. (2020). The continuing 2019-nCoV epidemic threat of novel coronaviruses to global health - The latest 2019 novel coronavirus outbreak in Wuhan, China. International Journal of Infectious Diseases, 91, 264-266. https://doi.org/10.1016/j.ijid.2020.01.009

Indonesia. (2020). KEPPRES NO 7 TH 2020 tentang gugus tugas percepatan penanganan corona virus disease 2019.

Indonesia. (2020). KEPPRES NO 12 TH 2020 tentang penetapan bencana nonalam penyebaran corona virus disease 2019 sebagai bencana nasional.

Indonesia. (2020). PERPRES NO 82 TH 2020 tentang komite penanganan corona virus disease 2019 (covid-19) dan pemulihan ekonomi nasional. 
Eric Fernardo:

Experimental Study Improves Covid-19 Health Protocol Compliance With High Threat and High Efficacy poster

Studi Eksperimen Meningkatkan Kepatuhan Protokol Kesehatan Covid-19 Dengan Poster Ancaman Tinggi dan Efikasi Tinggi

Indonesia. (2020). PERMENKES NO 9 TH 2020 tentang pedoman pembatasan sosial berskala besar dalam rangka percepatan penanganan corona virus disease 2019 (covid-19).

Jahangiry, L., Bakhtari, F., Sohrabi, Z., Reihani, P., Samei, S., Ponnet, K., \& Montazeri, A. (2020). Risk perception related to COVID-19 among the Iranian general population: an application of the extended parallel process model. BMC Public Health, 20(1), 1-8. https://doi.org/10.1186/s12889020-09681-7

Kementerian Kesehatan RI. (2020). Lima protokol penanganan jadi pedoman utama cegah dan kendalikan covid-19. Indonesia: Kementerian Kesehatan RI

Komite Penanganan Covid-19 dan Pemulihan Ekonomi Nasional. (2020). Selalu 3 M Cegah Peningkatan Penyebaran Covid-19 pada Komunitas dan Risiko Individu. https://setkab.go.id/selalu-3m-cegah-peningkatan-penyebarancovid-19-pada-komunitas-dan-risiko-individu/

Lee, M., \& You, M. (2020). Psychological and behavioral responses in South Korea during the early stages of coronavirus disease 2019 (COVID-19). International Journal of Environmental Research and Public Health, 17(9). https://doi.org/10.3390/ijerph17092977

Neuman, W. L. (2014). Social research methods: qualitative and quantitative approaches (Edisi 7). Pearson https://doi.org/10.2307/3211488

Nuryadi, Tutut Dewi Astuti, Endang Sri Utami, \& Martinus Budiantara. (2017). Dasar-Dasar Statistika Penelitian. http://lppm.mercubuanayogya.ac.id/wp-content/uploads/2017/05/Buku-Ajar_Dasar-DasarStatistik-Penelitian.pdf

O'keefe, D. J. (2016). Persuasion theory and research (Edisi 3). California, AS: Sage Publications.

Rothan, H. A., \& Byrareddy, S. N. (2020). The epidemiology and pathogenesis of coronavirus disease (COVID-19) outbreak. Journal of Autoimmunity, 109(February), 102433. https://doi.org/10.1016/j.jaut.2020.102433

Satgas Penanganan Covid-19. (2020). Peta Sebaran Kasus Covid-19 di Indonesia. https://covid19.go.id/peta-sebaran

Shirahmadi, S., Seyedzadeh-Sabounchi, S., Khazaei, S., Bashirian, S., Miresmæili, A. F., Bayat, Z., Houshmand, B., Semyari, H., Barati, M., Jenabi, E., Heidarian, F., Zareian, S., Kheirandish, M., \& Dadae, N. (2020). Fear control and danger control amid COVID- 19 dental crisis: Application of the Extended Parallel Process Model. PLoS ONE, 15(8 August), 1-12. https://doi.org/10.1371/journal.pone.0237490

Stephen W. Littlejohn, Foss, K. A., \& Oetzel, J. G. (2017). Theories of human communication. (Edisi 11). In Waveland Press, Inc. (Vol. 53, Issue 95). https://doi.org/10.1017/CBO9781107415324.004

Ulum, M. (2016). Buku uji validitas dan uji reliabilitas. Indonesia: STIKES WCH Malang.

Wimmer \& Dominick. (2003). Mass media research: an introduction. Ohio: Wadsworth Cengage Learning. 
Vol. 13, No. 2, Desember 2021, Hal 184 - 199

Witte, K. (1992). Putting the fear back into fear appeals: the extended parallel process model. Journal Communication Monographs Vol 59.

Worldometer. (2020). Coronavirus Update (Live): Cases and Deaths from COVID19 Virus Outbreak. www.worldometers.info

Yang, J., Wu, X., Sasaki, K., \& Yamada, Y. (2020). Changing health compliance through message repetition based on the extended parallel process model in the COVID-19 pandemic. PeerJ, 8, 1-14. https://doi.org/10.7717/peerj.10318 